\title{
Amino acids within the extracellular matrix (ECM) binding region (201- 218) of rat insulin-like growth factor binding protein (IGFBP)-5 are important determinants in binding IGF-I
}

\author{
S Bramani ${ }^{1}$, H Song ${ }^{1}$, J Beattie, E Tonner, D J Flint and G J Allan \\ Hannah Research Institute, Ayr, KA6 5HL, UK \\ ${ }^{1}$ These authors have contributed equally to the work. \\ (Requests for offprints should be addressed to G J Allan)
}

\begin{abstract}
The highly conserved $\mathrm{N}$ - and C-terminal domains of IGFBPs are believed to participate in IGF binding, but only recently have some of the critical residues in the IGFBP sequence involved in ligand binding been identified. Here we describe two highly conserved amino acids in the C-terminal domain of rat IGFBP-5 that are involved in binding IGF-I. Site-directed mutagenesis was used to produce two mutants, G203K and Q209A, of rIGFBP-5. Relative to wildtype rIGFBP-5, an 8-fold reduction in affinity for human IGF-I was found for recombinant G203K protein in both IGF-I ligand blots and solution phase ligand binding assays, and a 7- and 6-fold reduction for Q209A respectively. This shows that Gly203 and Gln209 in IGFBP-5 are important determinants in
\end{abstract}

binding IGF-I, and due to their complete conservation in all IGFBP sequences, we suggest that they are likely to be involved in binding IGF-I in all six binding proteins. In addition, these two non-basic residues lie within the ECM binding region (201-218) of IGFBP-5, demonstrating that the C-terminus contains partially overlapping IGF-I and ECM binding sites. We therefore propose that heparin binding to basic amino acids in IGFBP-5 between 201-218 may physically occlude subsequent interaction between IGF-I and Gly203/Gln209, and that this may explain previous work of others showing reduced affinity of ECM-bound IGFBP-5 for IGF-I.

\section{INTRODUCTION}

The mitogenic and metabolic effects of insulin-like growth factors (IGFs) are mediated mainly through the type 1 IGF receptor, which is found on the surface of most cell types (recently reviewed in Butler et al.1997). In turn, the bioavailability of IGFs is regulated by a family of IGF-specific binding proteins (IGFBPs; reviewed in Clemmons 1997). As the affinity constants of the IGFBPs are between 2- and 50-fold greater for binding IGFs than that of the IGF type 1 receptor, they can modulate IGF action by controlling the distribution of IGFs in biological fluids.

Comparisons of IGFBPs 1-6 indicate a high degree of conservation in the $\mathrm{N}$ - and $\mathrm{C}$-terminal regions. Of particular note are the largely conserved cysteine residues throughout IGFBPs 1-6 of all species sequenced so far. A non-conserved region separates the $\mathrm{N}$ - and $\mathrm{C}$-terminal domains. Both the $\mathrm{N}$ and C-terminal cysteine-rich domains of IGFBPs are believed to participate in IGF binding. This is suggested by the observations that $\mathrm{N}$-terminal cysteine-rich domains of IGFBP-1 (Huhtala et al.1986), IGFBP-3 (Sommer et al. 1991), IGFBP-4 (Chernausek et al. 1995), and IGFBP-5 (Andress et al. 1993) and C-terminal cysteine-rich domains of IGFBP-2 (Wang et al. 1988; Ho \& Baxter 1997) and IGFBP-3 (Binoux et al. 1991) all possess residual IGF binding activity. Despite this, to date only a limited number of mutational analyses of IGFBPs have been aimed at the identification of IGF binding domains.

Earlier work has shown that IGFBP-5 binding to extracellular matrix (ECM) results in a reduction in its affinity for IGF-I and enhancement of IGF-I biological actions (Andress \& Birnbaum 1992; Jones et al. 1993). This was confirmed by experiments 
demonstrating that incubation of IGFBP-5 with glycosaminoglycans (GAGs) resulted in a 17 -fold decrease in the affinity of IGFBP-5 for IGF-I (Arai et al. 1994). Amino acid substitution and peptide competition experiments have identified a sequence rich in basic amino acids in IGFBP-5 (between Arg201 and Arg218) that is involved in both heparin and ECM binding (Arai et al.1996; Parker et al. 1996.), and it was proposed that heparin binding to this region may produce a conformational change in IGFBP-5 that results in a reduction of affinity for IGF-I (Arai et al.1996). More recently, a systematic mutational analysis of this region has identified Arg207 and Arg214 as the most critical basic amino acids for binding ECM (Parker et al. 1998), and, in addition, has shown that mutation of 9 out of the 10 basic amino acids in this region had no effect on IGF-I binding.

Recently, work from several laboratories has begun to identify the specific amino acids in the IGFBP molecule that do contribute to IGF binding. At the N-terminus of bovine IGFBP-2, it was shown that Tyr60 was protected against iodination upon binding of IGFBP-2 to IGF-II (Hobba et al. 1996). Subsequently, the same group demonstrated that substitution of tyrosine-60 with alanine or phenyalanine leads to a 4.0- and 8.4-fold reduced affinity for IGF-I respectively, and a 3.5- and 4.0fold reduced affinity for IGF-II respectively (Hobba et al.1998). One suggestion is that the hydroxyl group of Tyr60 may participate in hydrogen bond formation that is important for the initial complex formation with IGF-I, and that this may be a common mechanism for all the IGFBPs, (with the exception of IGFBP-1 which has an alanine residue at the equivalent position). In support of this, others have carried out nuclear magnetic resonance spectroscopy on a bacterially expressed $\mathrm{N}$-terminal fragment of IGFBP-5 (residues 40-92). From this work it was proposed that the primary IGF binding domain comprises Val49, Tyr50 (equivalent to Tyr60 in IGFBP-2), Pro62 and Lys68 to Leu75, where the conserved Leu and Val residues localize in a hydrophobic patch on the surface of the IGFBP-5 protein (Kalus et al.1998). However, these researchers also demonstrate that the $\mathrm{N}$ terminal fragments of IGFBP-5 have a 10 to 200 fold lower affinity for IGFs than the full length protein, which agrees well with the reported reduced affinities of other $\mathrm{C}$-terminally truncated fragments of IGFBP-3 (Clemmons 1993) and IGFBP-5 (Andress et al.1993). This indicates that other residues at the C-terminus of the IGFBP proteins may be involved in the additional stabilization of IGF complex formation that leads to the very high affinity of binding.

Deletion between residues Cys205 to Val214 at the C-terminus of human IGFBP-4 has recently been shown to cause a 6-fold reduction in affinity for binding IGFs (Qin et al.1998). It is conceivable however that deletion of one of the very highly conserved cysteines in this region leads to a major change in the secondary structure of the C-terminal domain, as the six cysteines at the $\mathrm{C}$-terminus of bovine IGFBP-2 (bIGFBP-2) have been shown by Forbes et al to form disulphide bonds between consecutive residues (Forbes et al. 1998). These latter researchers also demonstrated that truncation of 48 residues from the C-terminus of bIGFBP-2 had no effect on IGF binding (equivalent to residue 200 in human IGFBP-4), suggesting that residues which contribute to IGF binding differ between IGFBP-2 and -4 . However, greater reduction in affinity for both IGFs was observed when 63 residues were deleted from the C-terminus of IGFBP-2, with a greater effect on IGF-II binding (up to 80-fold). This therefore identifies a critical region between amino acids 222-236 of bIGFBP-2 involved in binding IGFs (Forbes et al. 1998).

This critical region of bIGFBP-2 corresponds to amino acids $201-216$ in the rat IGFBP-5 (rIGFBP-5) sequence, which lies within the basic heparin binding region of the protein. Alignment of amino acid sequences for all six binding proteins from several species revealed that there are completely conserved glycine and glutamine residues (Gly203 and Gln209 in rIGFBP-5) within this region (Fig 1A), which, in turn, suggests an important conserved function for these amino acids. Using site directed mutagenesis, we have made two mutants of rIGFBP-5 (G203K and Q209A), and examined their affinity for binding human IGF-I (hIGF-I). We report here that the individual mutations both cause an approximately 8to 7-fold reduction in affinity for hIGF-I as shown both by IGF-I ligand blotting and solution phase ligand binding assays. The implications of these findings for IGFBP-5 interaction with both IGF-I and ECM are discussed.

\section{MATERIALS AND METHODS}

\section{Site-directed mutagenesis}

The full-length cDNA for rIGFBP-5 in pGEM $^{\circledR}-7 z f$ (Promega), containing both initiator and signal peptide, was kindly provided by Dr S. Guenette, Los 
Table 1. Affinity of wtIGFBP-5, G203K and Q209A for hIGF-I

\begin{tabular}{|l|c|c|c|c|}
\hline & \multicolumn{2}{|c|}{ Western Analysis } & \multicolumn{2}{c|}{ Scatchard Analysis } \\
\hline Protein & $\begin{array}{c}\text { Estimation of protein } \\
\text { concentration }(\mu \mathrm{g} / \mathrm{ml})\end{array}$ & $\begin{array}{c}\text { Affinity for hIGF-1: } \\
\% \mathrm{wt}\end{array}$ & $\begin{array}{c}\text { Estimation of protein } \\
\text { concentration }(\mu \mathrm{g} / \mathrm{ml})\end{array}$ & $\begin{array}{c}\text { Affinity for hIGF-I: } \\
\mathrm{K}_{\mathrm{D}}(\mathrm{nM})\end{array}$ \\
\hline wt BP-5 & 5.5 & 100 & 6.3 & 0.154 \\
\hline G203K & 6.9 & 12.5 & 8.1 & 1.25 \\
\hline Q209A & 7.8 & 15.0 & 11 & 0.84 \\
\hline
\end{tabular}

$\mathrm{K}_{\mathrm{D}}$ values were obtained by Scatchard analysis of binding data as described in the Methods section.

Angeles. It was subcloned into the EcoRI restriction site of $\mathrm{pFastBac}^{\circledR}$ (Gibco-BRL) for eventual expression in the baculovirus system. Site-directed mutagenesis was then performed at two separate sites on the rIGFBP-5 cDNA using the Gene Editor $^{\circledR}$ in vitro mutagenesis system (Promega). For the G203K mutation, the oligonucleotide 5'CCAACTGTGACCGCAAAAAATTCTACAAGA
GAAAGC-3' was used, which created a unique ApoI restriction site, and for Q209A it was 5'GATTCTACAAGAGAAAGGCATGCAAGCCTTC TCGTGG-3', which created a unique SphI restriction site. The products of the initial mutagenesis reactions were transformed into $E$. coli ES1301 mutS, a repair minus strain, to avoid selection against the desired mutations. Following mutagenesis, the DNA was

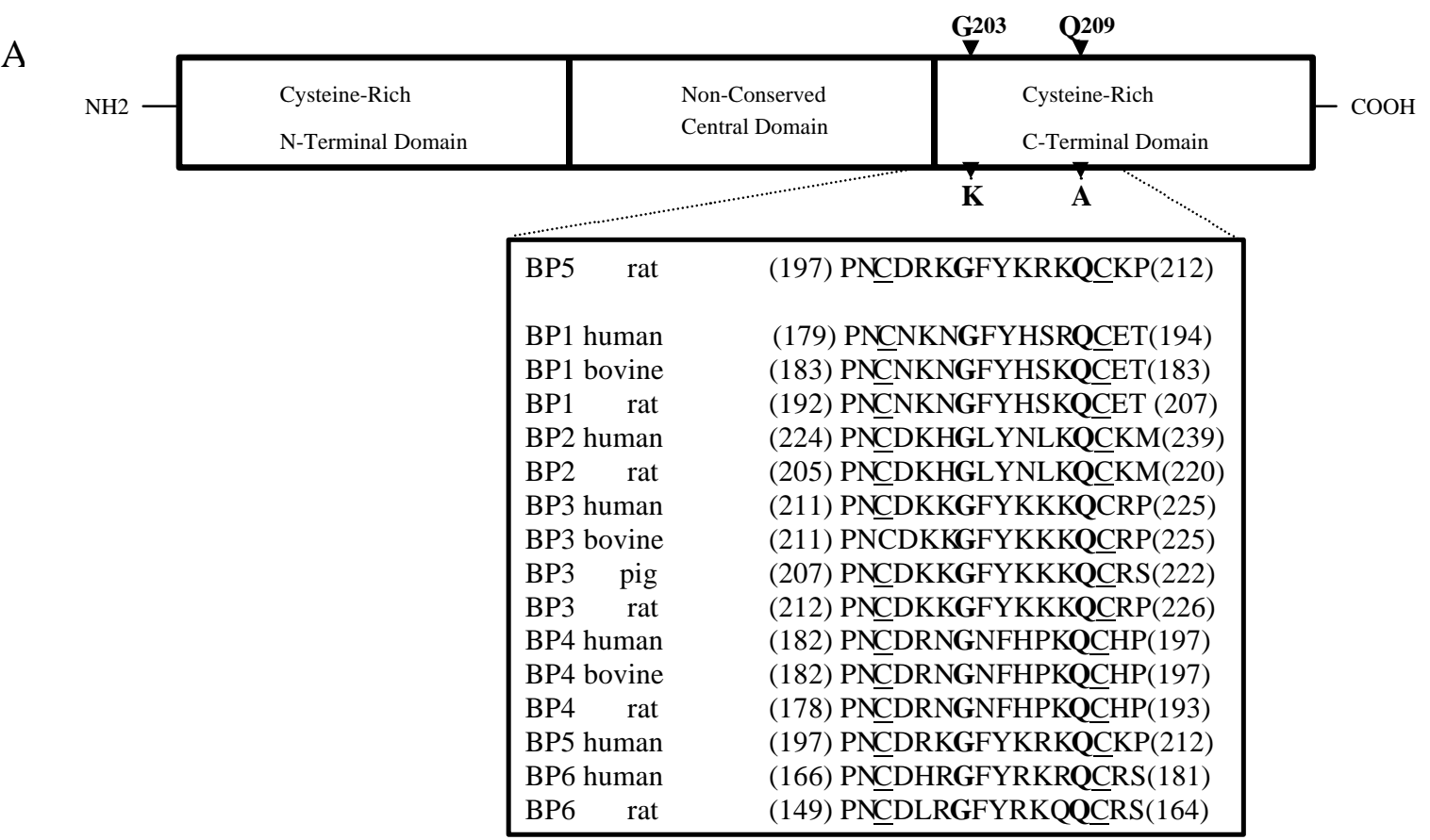

B 201- Arg-Lys-Gly-Phe-Tyr-Lys-Arg-Lys-Gln-Cys-Lys-Pro-Ser-Arg-Gly-Arg-Lys- $\underline{\operatorname{Arg}}$-218

FIGURE 1

A. C-terminal amino acid sequences of IGFBP. At the top is a schematic representation of the three structural domains of the IGFBPs. The relative location of the conserved glycine and glutamine residues are shown above the $\mathrm{C}$-terminal domain, and the substituted amino acids below. The box underneath shows a line-up of the amino acid sequences for this C-terminal region in all six IGFBPs from several different species. The residue number at the start and end of each sequence is indicated in brackets. The conserved cysteines are underlined and the G203 and Q209 are in bold. B. Amino acid sequence of the 201-218 region of IGFBP-5. Basic amino acids are underlined and Gly203 and Gln209 are in bold. 
maxi-prepped using the Qiagen Plasmid Maxi Prep Kit and manually sequenced using the T7 Sequenase $^{\mathrm{TM}}$ version 2.0 DNA sequencing kit (Amersham Life Sciences), which verified that the correct mutations were present.

\section{Baculovirus expression}

Expression of recombinant IGFBPs in the insect cell-baculovirus system was carried out using the Bac-to-Bac ${ }^{\circledR}$ system (Gibco-BRL), which employs the techniques of Lucklow et al. 1993 to produce recombinant virus. Conditions for expression were the same as that in the manufacturer's guide, with a chosen multiplicity of infection of 5. Sf9 insect cells (Spodoptera frugiperda) were grown in Sf-900 II medium (Life Technologies). $50 \mathrm{ml}$ suspension cultures were grown in spinner flasks (Techne) and culture supernatant containing secreted IGFBP protein was harvested 24 to 28 hours after infection, depending on the optimum level of expression of the individual protein. Supernatants were concentrated using $20 \mathrm{ml}$ Ultrafree-20 ${ }^{\circledR}$ (Millipore) columns and aliquots were frozen in liquid nitrogen and stored at $-70^{\circ} \mathrm{C}$.

\section{IGF-I Ligand Blotting}

Proteins were electrophoresed on $12 \%$ acrylamide SDS gels under non-reducing conditions and subsequently transferred to nitrocellulose membranes. Ligand blots were performed according to the method described by Hossenlopp et al. 1986, using IGF-I (GroPep) radiolabelled to a specific activity of approximately $100 \mu \mathrm{Ci} / \mu \mathrm{g}$. Following ligand analysis the same blots were used for immunodetection.

\section{Immunoblotting}

Western blotting of wt IGFBP-5, G203K and Q209A was performed to monitor protein loading of samples which had previously been subjected to ligand blot analysis. Immunodetection was with a sheep antibody raised in our laboratory to baculovirus-expressed wt rIGFBP-5 protein provided by Dr Sean Guenette (John Wayne Cancer Institute, Los Angeles). First antibody was used at a dilution of 1:2000 and anti sheep-HRP conjugate at 1:20,000. Reactivity was determined using Enhanced Chemiluminesence (ECL) (Amersham) and densitometric analysis (Molecular Dynamics).
Quantitation of wt IGFBP-5, G203K and Q209A in baculovirus supernatants was achieved by Western blot/densitometry using as standard wt IGFBP-5 supplied by Dennis Andress (Veterans Affairs Medical Center, Seattle). Care was taken to operate with standards and samples within the linear range of the ECL/Film response methodology. Using this technique protein concentrations of 5.5, 6.9 and 7.8 $\mu \mathrm{g} / \mathrm{ml}$ were found for wt IGFBP-5, G203K and Q209A respectively (Table 1).

\section{Solution Phase Assay of IGFBP activity}

Activity of wt IGFBP-5, G203K and Q209A were assessed in solution by the method described by Conover et al. 1989. Amounts of wt, G203K and Q209A proteins were present in assay tubes such that approximately $20 \%$ of added ${ }^{125}$ I-IGF-I (25-30,000 $\mathrm{cpm}$ ) was bound. Affinity of wt and mutated IGFBP5 proteins was assessed by Scatchard analysis of binding curves obtained following addition of increasing concentrations of unlabelled IGF-I. Protein concentrations as estimated by Scatchard are 6.3, 8.1 and $11 \mu \mathrm{g} / \mathrm{ml}$ for wt IGFBP-5, G203K and Q209A respectively (Table 1).

\section{RESULTS AND DISCUSSION}

Two amino acids in the C-terminus of IGFBPs (Gly203 and Gln 209 in IGFBP-5) are completely conserved between all six binding proteins from all species sequenced to date (Fig 1A). In this work, we demonstrate that these residues in rIGFBP-5 are important determinants in binding IGF-I. Wild-type IGFBP-5 and the two mutants G203K and Q209A were probed with ${ }^{125} \mathrm{I}$ - labelled IGF-I in ligand blots, and the same blots were subsequently probed with a sheep anti-IGFBP-5 polyclonal antisera (Fig 2A). The IGFBP-5 doublet produced by expression in the baculovirus system is a common feature from several laboratories (personal communications Dr D. Andress, Dr S. Guenette), including commercially available hIGFBP-5 (Austral Biologicals), and this may be the result of inefficient cleavage of the mammalian signal peptide during secretion. Nevertheless, BiaCore analysis of the wt IGFBP5/hIGF-I and -II interaction recorded a single association and dissociation event (data not shown), suggesting that the IGFBP-5 doublet represents a single species with respect to IGF-I binding. Also, the strong recognition of the mutant proteins with our IGFBP-5 antibody demonstrates their immunological integrity. Densitometry was carried out on ligand and 
A

\section{wt G203K Q209A}

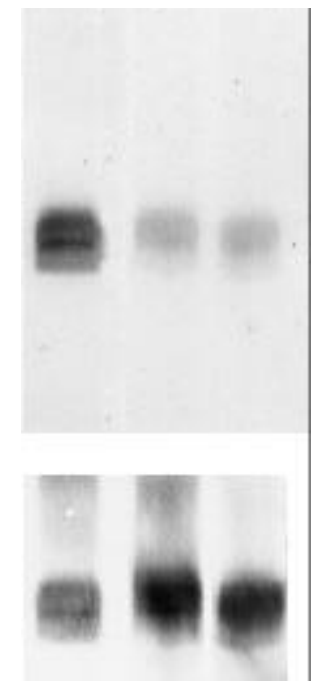

B

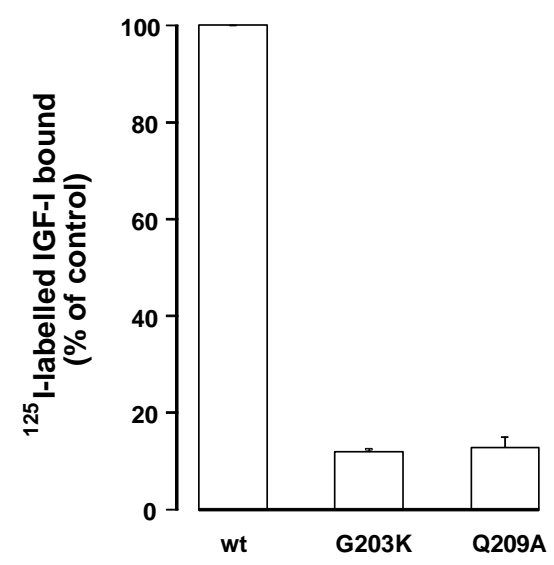

FIGURE 2. Western analysis of wild-type and mutant protein.

A. Both autoradiographs were produced from a single western blot. The upper autoradiograph is a ligand blot of wt rIGFBP-5 protein and the two mutant proteins G203K and Q209A probed with ${ }^{125}$ I-hIGF-I. The lower autoradiograph is the same blot subsequently probed with sheep anti-rIGFBP-5 polyclonal antisera.

B. Histogram showing the results of a densitometric analysis of the upper autoradiograph in $2 \mathrm{~A}(\mathrm{n}=2 \pm$ range).

western blots from two separate experiments and the ratio between the strength of signal in ligand and western blot determined (Fig 2B; Table 1). This demonstrated that, relative to wt IGFBP-5, G203K and Q209A have an 8- and 7-fold reduction in affinity for IGF-I respectively.

This is in very strong agreement with the $K_{d}$ values derived from solution phase binding assays for these three proteins (Fig 3; Table 1). The $\mathrm{K}_{\mathrm{d}}$ of wt IGFBP-5 in our experiments is also in agreement with previous results using mammalian and yeast expressed protein (Kiefer et al.1992), but we demonstrate that, relative to wt IGFBP-5, G203K and Q209A have a 8- and 6-fold reduction in affinity for IGF-I respectively (Table 1). Forbes et al 1998 demonstrated up to an 80-fold reduction in IGF-II affinity when the equivalent amino acids (222-236) were deleted from bIGFBP-2. This larger reduction in affinity may be a result of differential IGF-I and -II recognition. Alternatively, loss of both conserved amino acids may explain the larger effect. The affinity of a double mutation in rIGFBP5 (G203K, Q209A) for both IGF-I and -II is the subject of ongoing research in our laboratory. Note, however, that the C-terminal truncated bIGFBP-2 proteins may have lost other residues involved in IGF binding. Indeed, smaller truncations did appear to alter IGF binding specificity selectively, suggesting that other more $\mathrm{C}$-terminal residues may be involved in differential IGF-I and -II recognition (Forbes et al. 1998).

A myriad of functions has now been ascribed to the basic amino acid rich region between Arg201 and Arg218 in IGFBP-5. In addition to heparin and ECM binding (Arai et al. 1996; Parker et al.1996), this region has been implicated in binding to the acid labile subunit (Twigg et al. 1998), the putative IGFBP-5 receptor (Andress 1998), plasminogen activator inhibitor-I (Nam et al. 1997), and has even been postulated to have strong homology to a nuclear localization signal (Schedlich et al. 1998) and the DNA-binding domains of several transcription factors (Schedlich et al 1998; Turner \& Tijan 1989). Recently, a systematic mutational analysis of this region, using either single or combined substitutions of basic amino acids, has identified the critical residues involved in ECM binding (Parker et al. 1998). While some of these mutations displayed major reductions in ECM binding, they were shown to have little effect on IGF-I affinity, and it was concluded that the 201-218 region was not involved in binding IGF-I.

It is, therefore, of major significance that two of the non-basic amino acids lying within this region have now been shown to be involved in IGF-I binding. In the linear sequence, Gly203 and Gln209 flank a 


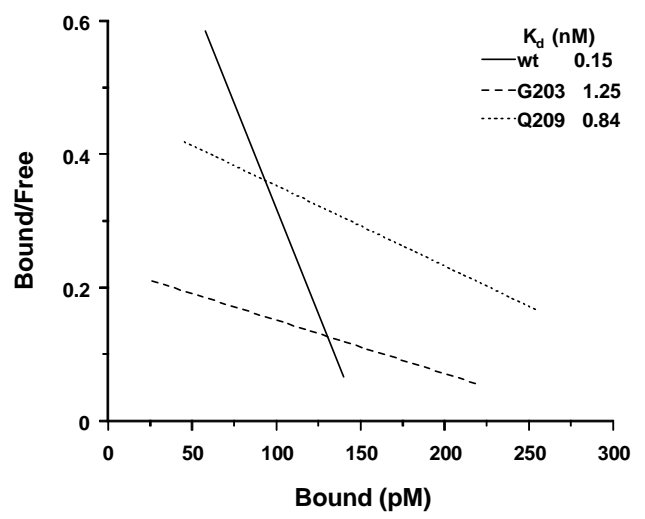

FIGURE 3. Regression lines drawn through the data obtained by Scatchard analysis of hIGF-I binding to wt IGFBP-5 (solid line: $\mathrm{y}=-0.0063 \mathrm{x}+0.95(\mathrm{r}=-0.94)), \mathrm{G} 203 \mathrm{~K}$ (dashed line: $\mathrm{y}=$ $-0.0008 \mathrm{x}+0.23(\mathrm{r}=-0.96))$ or Q209A (dotted line: $\mathrm{y}=$ $-0.0012 \mathrm{x}+0.47(\mathrm{r}=-0.77))$. IGFBPs were present at $1.1,6.9$ and $7.4 \mathrm{ng} /$ tube for wt, G203K and Q209A respectively. $\mathrm{K}_{\mathrm{d}}$ values were determined from these plots and are as indicated in the Figure. This experiment was performed twice and similar results were obtained in each instance.

critical residue involved in ECM binding (Arg207), and, in turn, are themselves flanked by other basic residues which play a part in this interaction (Fig 1B). In addition, a helical wheel prediction of the 201-218 region of IGFBP-5 (Parker et al.1998), places Gly203 adjacent to the critical ECM binding residues, while Gln209 is flanked by two further basic residues elsewhere in the wheel. Thus, we have demonstrated that IGF-I and ECM binding sites in IGFBP-5 are in very close proximity and may partially overlap.

This has important implications for the function of IGFBP-5. Heparin or ECM binding to the basic amino acids in the 201-218 region of IGFBP-5 may physically occlude any subsequent interaction between Gly203/Gln209 and IGF-I. This would offer an alternative explanation for the observed reduced affinity of ECM/GAG bound IGFBP-5 for IGF-I (Andress et al. 1992; Jones et al 1993.; Arai et al.1994), rather than a heparin induced conformational change in IGFBP-5 which alters an IGF binding domain elsewhere in the protein. The lower affinity of ECM-bound IGFBP-5 for IGF-I may be biologically important for obtaining the correct balance between soluble IGF-I available for binding the type 1 IGF receptor and a reservoir of immobilised IGF-I protected from proteolysis while bound to the ECM.

In summary, we have identified two highly conserved C-terminal residues in IGFBP-5 involved in IGF-I binding. Due to the complete conservation of these two amino acids in all IGFBP sequences, we suggest that they are likely to be involved in binding IGF-I in all six of the binding proteins. Overlap of these residues in IGFBP-5 with other amino acids between 201-218, that have been shown to be involved in ECM binding, suggests their involvement in the interaction between IGFBP-5, ECM and IGF-I.

\section{ACKNOWLEDGEMENTS}

We thank Dr Sean Guenette, John Wayne Cancer Institute, Los Angeles, for the rIGFBP-5 cDNA and recombinant wt IGFBP-5 protein that was used to raise sheep antiserum. This work was supported by the Scottish Office, Agriculture, Environment and Fisheries Department.

\section{REFERENCES}

Andress DL \& Birnbaum RS 1992 Journal of Biological Chemistry 267 22467-22472.

Andress DL, Loop SM, Zapf J \& Kiefer MC 1993 Biochemical and Biophysical Research Communication. 195 25-30.

Andress DL 1998 American Journal of Physiology 274 E744E750.

Arai T, Parker A, Busby W Jr \& Clemmons DR 1994 Journal of Biological Chemistry 269 20388-20393.

Arai T, Clarke J, Parker A, Busby W Jr, Nam T \& Clemmons DR 1996 Journal of Biological Chemistry 271 6099-6106.

Binoux M, Roghani M, Hossenlopp P, Hardouin S \& Gourmelen M 1991 Acta Endocrinology. (Copenhagen) 124 41-47.

Butler AA, Yakar S, Gewolb IH, Karas M, Okubo Y \& LeRoith D 1998 Comparative Biochemistry and Physiology- BBiochemistry and Molecular Biology 121 19-26.

Chernausek SD, Smith CE, Duffin KL, Busby WH, Wright G \& Clemmons DR 1995 Journal of Biological Chemistry 270 11377-11382.

Clemmons DR 1993 Molecular Reproduction and Development 35 368-375.

Clemmons DR 1997 Cytokine Growth Factor Review 8 45-62.

Conover CA, Lim F, Powell D, Rosenfeld RG \& Hintz RL 1989 Journal of Clinical Investigation 83 852-859.

Forbes BE, Turner D, Hodge SJ, McNeil KA, Forsberg G \& Wallace JC 1998 Journal of Biological Chemistry 2734647 4652.

Ho PJ \& Baxter RC 1997 Endocrinology 138 3811-3818.

Hobba GD, Forbes BE, Parkinson EJ, Francis GL \& Wallace JC 1996 Journal of Biological Chemistry 271 30529-30536.

Hobba GD, Lothgren A, Holmberg E, Forbes BE, Francis GL \& Wallace JC 1998 Journal of Biological Chemistry 273 1969119698.

Hossenlopp P, Seurin D, Segovia-Quinson B, Hardouin S \& Binoux M 1986 Analytical Biochemistry 154 138-143.

Huhtala ML, Koistinen R, Palomaki P, Partanen P, Bohn H \& Seppala M 1986 Biochemical and Biophysical Research Communication 141 263-270.

Jones JI, Gockerman A, Busby WH, Camacho-Hubner C \& Clemmons DR 1993 Journal of Biological Chemistry 121679 687.

Kalus W, Zweckstetter M, Renner C, Sanchez Y, Georgescu J, Grol M, Demuth D, Schumacher R, Dony C, Lang K \& Holak TA 1998 EMBO Journal 17 6558-6572. 
Kiefer MC, Schmid C, Waldvogel M, Schlapfer I, Futo E, Masiarz FR, Green K, Barr PJ \& Zapf J 1992 Journal of Biological Chemistry 267 12692-12699.

Lucklow VA, Lee SC, Barry GF \& Olins PO 1993 Journal of Virology 67 4566-4579.

Nam TJ, Busby W Jr \& Clemmons DR 1997 Endocrinology 138 2972-2978.

Parker A, Badley-Clarke J, Busby WH Jr \& Clemmons DR 1996 Journal of Biological Chemistry 271 13523-13529.

Parker A, Rees C, Clarke J, Busby WH Jr \& Clemmons DR 1998 Molecular Bioliogy of the Cell 9 2383-2392.

Qin X, Strong DD, Baylink DJ \& Mohan S 1998 Journal of Biological Chemistry 273 23509-23516.

Schedlich LJ, Young TF, Firth SM \& Baxter RC 1998 Journal of Biological Chemistry 273 18347-183.

Sommer A, Maack CA, Spratt SK, Mascarenhas D, Tressel TJ, Rhodes ET, Less R, Roumas M, Tatsuro GP, Flynn JA, Gerber N, Taylor J, Cudney H, Nanney L, Hunt TK \& Spencer EM 1991 In Modern Concepts of Insulin-like Growth Factors, pp 329-336. Ed EM Spencer Elsevier Science Publishing Co, Inc, New York.

Turner R \& Tjian R 1989 Science 243, 1689-1694

Twigg SM, Kiefer MC, Zapf J \& Baxter RC 1998 Journal of Biological Chemistry 273 28791-28798.

Wang JF, Hampton B, Mehlman T, Burgess WH \& Rechler MM 1988 Biochemical and Biophysical Research Communication 157 718-726 